\title{
A MUTAÇÃO (IN)CONSTITUCIONAL DO RITO DO IMPEACHMENT NO SENADO FEDERAL
}

\section{THE (IN)CONSTITUTIONAL MUTATION OF THE RITE OF IMPEACHMENT IN} THE SENATE

${ }^{1}$ Martonio Mont'Alverne Barreto Lima

\section{Resumo}

O trabalho discute a interpretação conferida ao artigo 52, parágrafo único, da Constituição Federal, pela qual o Presidente do Supremo Tribunal Federal autorizou a separação do rito do impeachment no Senado Federal em dois momentos: inicialmente, foi votada a possibilidade da perda do cargo, e, posteriormente, os Senadores manifestaram-se sobre a imputação da inabilitação, por oito anos, para o exercício de função pública da então Presidenta Dilma Rousseff. Propõe-se a coerência hermenêutica do Judiciário, sob o enfoque da jurisdição constitucional.

Palavras-chave: Democracia; Impeachment; Hermenêutica Constitucional; Controle Político; Supremo Tribunal Federal.

\begin{abstract}
The work discusses the interpretation given to article 52, sole paragraph, of the Federal Constitution, which was authorized by the President of the Supreme Court, the separation of the rite of impeachment in the Senate in two phases: initially, was voted the possibility of loss of Office, and, later, the senators were on the imputation of disqualification for eight years, for the exercise of a public function of the then President Dilma Rousseff. It is proposed that the consistency of the judiciary hermeneutics, under the approach of judicial review.
\end{abstract}

Keywords: Democracy; Impeachment; Constitutional Hermeneutics; Political Control; Supreme Court.

${ }^{1}$ Doutor e Pós-Doutor em Direito pela Johann Wolfgang Goethe-Frankfurt,(Alemanha). Mestre em Direito pela Universidade Federal do Ceará, UFC - CE. Professor Titular da Universidade de Fortaleza, UNIFOR - CE, (Brasil). Procurador do Município de Fortaleza

${ }^{2}$ Mestranda em Direito Constitucional na Universidade de Fortaleza, UNIFOR - CE, (Brasil). Advogada.E,mail: alicepinheiro2190@gmail.com 


\section{INTRODUÇÃO}

Impeachment é expressão de origem inglesa e significa "impedimento" ou "impugnação". O sentido jurídico atribuído pode ser interpretado de duas maneiras: como o processo instaurado para averiguar se determinado ocupante de cargo público praticou crime de responsabilidade; ou, sob outro enfoque, é a denominação dada a uma das sanções impostas após a condenação pela infração político-administrativa apurada, que corresponde à perda do cargo.

Podem, então, ser responsabilizados politicamente o Presidente e o Vice Presidente da República; os Ministros de Estado, nos crimes conexos com aqueles praticados pelo Presidente da República; os Ministros do STF; os membros do Conselho Nacional de Justiça e do Conselho Nacional do Ministério Público; o Procurador Geral da República; o Advogado Geral da União; os Governadores e, por fim, os Prefeitos.

Será analisado o procedimento do impeachment aplicável ao Presidente da República, previsto em alguns dispositivos da Constituição Federal e na Lei $n^{\circ} 1.079 / 50$, os quais atribuem a qualquer cidadão, em pleno gozo de seus direitos políticos, a legitimidade para propor, por escrito, a abertura do processo para apurar crime de responsabilidade perante a Câmara dos Deputados.

Em específico, o enfoque deste trabalho será a análise do julgamento do impeachment perante o Senado Federal, ocorrido em 31 de agosto de 2016, momento em que fora suscitada questão de ordem ao Presidente do STF sobre a possibilidade da separação da votação dos Senadores em dois momentos: primeiro, seria votada a ocorrência de crime de responsabilidade e, depois, em nova votação, os parlamentares deveriam manifestar se seria aplicada a sanção constitucional de inabilitação prevista, considerando-a, assim, autônoma. 
Diante dessas considerações, buscou-se desenvolver pesquisa para responder aos seguintes questionamentos: o entendimento do STF sobre a separação das votações no julgamento do impeachment de Fernando Collor foi o mesmo adotado no de Dilma Rousseff? Poderia o STF mudar seu entendimento sobre penas aplicado ao caso Collor para passar a entender diferente no caso Dilma? Quais os limites hermenêuticos aplicados ao STF?

Disso se extrai a adequação do estudo à área de concentração de Direito Constitucional Público, em específico, à linha de pesquisa denominada "Teoria Constitucional”, conforme o Anexo II do edital de seleção, em específico, quanto aos temas hermenêutica e mutação constitucional.

A justificativa para este trabalho diz respeito ao aprimoramento do senso crítico, que é enriquecido quando do debate acerca das inovações hermenêuticas que surgem no cenário jurídico e político brasileiro e suas consequências para a efetivação da segurança jurídica almejada em um Estado Democrático de Direito.

O trabalho tem como objetivo geral analisar a atuação do Poder Judiciário quando demandado acerca de questão política e jurídica, bem como apresenta os seguintes objetivos específicos: verificar se a postura adotada no caso do impeachment da Presidenta Dilma Rousseff foi o mesmo utilizado no caso do ex-Presidente Fernando Collor de Mello; identificar os argumentos que autorizaram a nova interpretação constitucional sem alteração de texto e sua validade; observar os limites da atuação jurisdicional, em atenção à separação das funções estatais, a fim de se evitar a ingerência desmedida de um Poder sobre o outro; e, por fim, analisar a necessidade, ou não, de o Judiciário se vincular aos seus próprios julgados.

A metodologia utilizada caracteriza-se como um estudo descritivo-analítico, desenvolvido através de pesquisa bibliográfica, por meio da consulta a livros, publicações especializadas, artigos e sítios eletrônicos, o que possibilitou fazer uma análise crítica acerca do processo de impeachment no Brasil. 
No que tange à tipologia, classifica-se como pura, pois tem como propósito, simplesmente, a ampliação dos conhecimentos dos pesquisadores. Quanto à abordagem, é qualitativa, para que os pesquisadores alcancem um posicionamento próprio sobre o assunto, bem como busca averiguar a temática desse trabalho nos casos concretos.

Quanto aos objetivos, a pesquisa é descritiva, por explicitar, classificar e esclarecer o problema apresentado, e exploratória, uma vez que procurará aprimorar ideias, ofertando maiores informações sobre a temática em foco.

Pretende-se, então, verificar a pertinência do assunto abordado, considerando a sua repercussão social e a necessidade de aprimorar o senso crítico sobre a atuação do Judiciário quando realiza mutação sobre dispositivos constitucionais. Nesse sentido, para fins didáticos, o presente trabalho divide-se em três capítulos, distribuídos na forma explicitada a seguir.

O primeiro capítulo aborda o trâmite empregado ao impeachment da Presidenta da República. Para tanto, serão abordadas as principais fases ocorridas na Câmara dos Deputados e no Senado Federal, com ênfase no julgamento da ADPF 378, bem como serão apresentados os questionamentos suscitados sobre o procedimento em cada uma das Casas Legislativas.

O segundo capítulo trata, especificamente, da análise do pedido de modificação do rito do impeachment no Senado Federal, que objetivou consolidar a separação da votação final em dois momentos, como se verá adiante. Será, também, objeto de discussão a análise comparativa do posicionamento do STF sobre a natureza das penas no julgamento do caso de Fernando Collor e de Dilma Rousseff.

Por fim, no terceiro capítulo observa-se, criticamente, a abordagem do constitucionalismo, da ordem democrática e da soberania popular, sob a justificativa de se verificar o instituto da mutação constitucional e de se questionar sobre a vinculação do STF às próprias decisões, sob o prisma da segurança jurídica. 
Esse trabalho, então, propõe uma visitação ao tema do impeachment, à luz da temática da jurisdição constitucional, da autonomia parlamentar e da mutação constitucional, no afã de analisar a harmonia e independência dos poderes.

\section{O RITO BIFÁSICO DO IMPEACHMENT NO ORDENAMENTO JURÍDICO BRASILEIRO}

O sistema jurídico brasileiro adota um procedimento bifásico para análise do impeachment, contemplando a apreciação tanto da Câmara dos Deputados quanto do Senado Federal. Oportuniza-se, portanto, que ambas as Casas do Congresso Nacional manifestem suas convicções, como representantes dos interessados que os legitimaram.

Este trabalho trata especificamente do momento final de votação vivenciado pelos Senadores da República, contudo é importante expor o trâmite percorrido, desde o recebimento da denúncia pelo Presidente da Câmara dos Deputados até a votação em separado no âmbito do Senado Federal para a completude do estudo.

Primeiro, será dado destaque ao procedimento instaurado na Câmara dos Deputados, em especial, será feita referência ao julgamento da ADPF 378, e, posteriormente, será analisado o trâmite perante o Senado Federal e todas as suas peculiaridades.

\subsection{O trâmite perante a Câmara dos Deputados}

No dia 02 de dezembro de 2015, o então Presidente da Câmara dos Deputados, Eduardo Cunha, recebeu o pedido de impeachment da Presidenta Dilma Rousseff, protocolado pelos juristas Hélio Bicudo, Miguel Reale e Janaína Paschoal cujos fundamentos diziam respeito às seguintes condutas: crime de responsabilidade pela abertura de créditos suplementares por decreto presidencial, sem autorização do Congresso Nacional e quando já, supostamente, sabia do descumprimento da meta fiscal prevista na LDO; crime de responsabilidade pela contratação ilegal de operações de crédito, as denominadas "pedaladas fiscais"; e, por fim, crime de responsabilidade pelo não registro de valores no rol de passivos da dívida líquida do setor público. 
Em 08 de dezembro de 2015, foi eleita Comissão Especial, formada por 65 Deputados Federais titulares e mais 65 suplentes, com função de analisar a denúncia e emitir um parecer sobre a procedência ou não das alegações formuladas. Além disso, após a formação da Comissão, houve a propositura de Arguição de Descumprimento de Preceito Fundamental (ADPF) no 378, pelo Partido Comunista do Brasil (PCdoB), requerendo ao Supremo Tribunal Federal o reconhecimento da inconstitucionalidade de alguns dispositivos e interpretações da Lei ${ }^{\circ}$ 1.079/50. Alguns dos pontos questionados foram: a possibilidade de defesa prévia da Presidente da República; a anulação da eleição da Comissão Especial ocorrida em 08 de dezembro de 2015, em razão de ter sido realizada por voto secreto e mediante chapa avulsa, em contrariedade ao que foi acordado pelos líderes dos partidos; a obrigatoriedade do acolhimento do pedido de impeachment pelo Senado Federal; Suspeição do Presidente Eduardo Cunha, dentre outros temas.

No julgamento da ADPF 378 decidiu-se que: não há que se falar em direito de defesa prévia da Presidenta da República antes do recebimento da denúncia pelo Presidente da Câmara; não pode haver chapa avulsa e a votação deve ser aberta pelo Plenário; o Senado não está obrigado a processar e julgar o Presidente após o recebimento dos autos da Câmara- deve fazer seu próprio juízo de admissibilidade; e ficou resolvida a inexistência de suspeição de Eduardo Cunha para a condução dos trabalhos.

O Deputado Jovair Arantes, relator da Comissão Especial, recomendou a abertura do processo de impeachment para averiguar as condutas imputadas. Seu parecer foi aprovado pelos membros da Comissão Especial, por 38 votos a 27. Em seguida, foi realizada a votação no Plenário da Câmara dos Deputados, a qual resultou na admissibilidade do prosseguimento do rito processual perante o Senado Federal com a seguinte votação: 367 a favor; 137, contrários; 7 abstenções e 2 ausências.

Com a aprovação da abertura do processo de impeachment, seguiram os autos para o conhecimento e apreciação do Senado Federal, responsável pelo processo e julgamento de quem exerce o cargo de Presidente da República, como será visto adiante.

\subsection{O trâmite perante o Senado Federal}


Após o julgamento da ADPF 378, o Supremo Tribunal Federal decidiu que a decisão de admissibilidade do processo de impeachment pela Câmara dos Deputados não vincula o Senado Federal, que, então, exerce sua função de processar e julgar o Presidente da República de forma autônoma.

Ao chegar o processo no Senado Federal, foi constituída uma Comissão Especial para análise da procedência ou improcedência da denúncia em desfavor da Presidenta da República, sob a direção do Senador Raimundo Lira e relatoria do Senador Antônio Anastasia.

Foram marcadas e realizadas audiências públicas, com a oitiva de diversos interessados no processo, como os autores da denúncia, o ex Ministro do STF, Carlos Velloso, e o Advogado Geral da União, José Eduardo Cardozo, dentre outros. Em 04 de maio de 2016, o relator, Senador Antônio Anastasia, vota favoravelmente à abertura do impeachment e é acompanhado pela maioria dos demais Senadores no Plenário. Por conseguinte, a Presidente foi afastada de suas funções por até 180 dias.

Instaurado o processo perante o Senado Federal, o Presidente do Supremo Tribunal Federal assumiu a condução do impeachment, em atenção ao artigo 52, parágrafo único, da Constituição Federal e assinou o mandado de citação da Presidente afastada, atribuindo-lhe prazo de 20 dias para se defender.

Em nova reunião, a Comissão Especial do Senado aprovou cronograma para a fase de instrução probatória, com previsão de prazo da oitiva de testemunhas e também da Presidente afastada, encerrando essa fase com a confecção de novo relatório. José Eduardo Cardozo entrega à Comissão a defesa escrita de Dilma Rousseff e, após o cumprimento das fases marcadas no calendário, o Relator, Senador Anastasia, apresenta relatório final e defende a procedência da acusação, com a consequente instalação da fase de julgamento, o qual fora acompanhado pela maioria dos Senadores da Comissão. 
Segue o relatório para votação perante o Plenário do Senado, sob a presidência do Ministro do STF, Ricardo Lewandowski. Por maioria dos votos, os Senadores decidiram por acatar o parecer da Comissão e definitivamente instaurar a fase processual naquela Casa Legislativa. Após 48 horas, o advogado de defesa entregou as argumentações finais, mantendo a tese de que a abertura de créditos suplementares e os atrasos nos repasses ao Banco do Brasil não configuraram crime de responsabilidade.

Em 25 de agosto de 2016, foi iniciado o julgamento da Presidenta Dilma Rousseff. Nesse período, foram suscitadas diversas questões de ordem, foram ouvidas as últimas testemunhas e também colhido o depoimento de Dilma Rousseff, culminando com a entrega das alegações finais da acusação e da defesa.

Em 31 de agosto de 2016, foi acolhido pelo Ministro Ricardo Lewandowski o pedido da defesa para que houvesse a análise em separado das penas atribuídas em razão da condenação por crime de responsabilidade, sob manto de novo fundamento hermenêutico. Este desmembramento configura, então, o objeto central de análise crítica deste trabalho.

No próximo capítulo, será feita análise mais detida acerca da postura do Presidente do Supremo Tribunal Federal, enquanto condutor do processo de impeachment no Senado Federal, bem como se propõe um estudo comparativo sobre a interpretação conferida ao artigo 52, parágrafo único, da Constituição Federal tanto no caso Collor quanto no caso Dilma.

\section{HERMENÊUTICA CONSTITUCIONAL: ANÁLISE DA SEPARAÇÃO DA VOTAÇÃO DO IMPEACHMENT NO SENADO FEDERAL}

O sistema constitucional é formado por normas cuja manifestação se perfaz por meio de princípios e de regras, sem qualquer distinção hierárquica entre si. Cada uma dessas espécies normativas tem sua relevância e desempenha funções complementares. Ronald Dworkin (2002, p.39) enfatiza a distinção entre esses padrões normativos e, em seguida, enaltece como devem ser utilizados os comandos normativos proferidos por uma regra no sistema jurídico: 
A diferença entre princípios jurídicos e regras jurídicas é de natureza lógica. Os dois conjuntos de padrões apontam para decisões particulares acerca da obrigação jurídica em circunstâncias especificas, mas distinguem-se quanto à natureza da orientação que oferecem. As regras são aplicáveis à maneira do tudo-ou-nada. Dados os fatos que uma regra estipula, então ou a regra é válida e, neste caso, a resposta que ela fornece deve ser aceita ou não é válida, e neste caso nada contribui para a decisão.

Além da diferenciação entre os dois padrões normativos, Humberto Ávila (2007, p.112-114) indica a importância do respeito às regras dispostas no texto constitucional, como mecanismo que objetiva evitar arbitrariedades e enseja uma maior segurança jurídica, em razão de ser um padrão normativo mais rígido. Dessa forma, menciona o referido autor:

As regras não devem ser obedecidas somente por serem regras e serem editadas por uma autoridade. Elas devem ser obedecidas, de um lado, porque sua obediência é moralmente boa e, de outro, porque produz efeitos relativos a valores prestigiados pelo próprio ordenamento jurídico, como segurança, paz e igualdade.

Citar a supremacia do Poder Legislativo significa evidenciar a figura democrática, que, através dos processos legislativos de criação dos padrões normativos, concretizam a vontade do povo, titular da soberania. Isso enaltece o fato de que não se deve consolidar o sistema jurídico apenas no plano formal, mas também material. Sobre a temática, Norberto Bobbio (1997, p. 171) trata do governo das leis, que se aperfeiçoa com o rigoroso respeitos às normas:

O governo das leis celebra hoje o próprio triunfo na democracia. E o que é a
democracia se não um conjunto de regras (as chamadas regras do jogo) para a
solução dos conflitos sem derramamento de sangue? E em que consiste o bom
governo democrático se não, acima de tudo, no rigoroso respeito a estas regras?
Pessoalmente, não tenho dúvidas sobre a resposta a estas questões. E exatamente
porque não tenho dúvidas, posso concluir tranquilamente que a democracia é o
governo das leis por excelência. No momento mesmo em que o regime democrático
perde de vista este seu princípio inspirador, degenera rapidamente em seu contrário,
numa das tantas formas de governo autocrático de que estão repletas as narrações
dos historiadores e as reflexões dos escritores políticos.

Isso significa a necessidade do devido respeito aos ditames normativos, principalmente, quanto às modificações que se pretendem concretizar nos textos constitucionais. O Judiciário não é livre para alterar a Constituição, seja por meio de emendas ou por mutações, estas últimas as mais temerosas à segurança jurídica. 


\subsection{A hermenêutica e os mecanismos de mudança do texto constitucional}

As constituições devem ser interpretadas para que se alcance o real significado dos seus termos, levando em consideração fatores históricos, econômicos e políticos do Estado. Entretanto, a atividade do hermeneuta se justifica apenas quando o texto constitucional assim possibilitar, em razão de determinados comandos serem autoaplicáveis e, por si sós, compreendidos, como é o caso das regras constitucionais.

Dessa forma, para que haja interpretação, pressupõe-se a existência de obscuridade ou antinomia aparente entre normas de um sistema jurídico. Como forma de resguardar a segurança jurídica, o ordenamento brasileiro adotou critério rígido para o processo de elaboração, formação e alteração da norma constitucional. Partindo-se desse parâmetro, a Constituição poderia ser alterada, desde que respeitados os limites do Poder Constituinte Originário, por mecanismos formais, como a reforma, ou informais, através da mutação constitucional.

A reforma consiste na alteração do texto constitucional, com a observância de procedimentos específicos delimitados pelo Poder Constituinte Originário, denominados emendas constitucionais, através da atuação do Poder Legislativo. Para tanto, é necessário um quórum de três quintos dos votos dos respectivos membros, em cada Casa do Congresso Nacional, em dois turnos de votação para que seja efetivada a alteração, supressão ou acréscimo de texto constitucional.

Já a mutação constitucional consiste em mecanismo informal, que resultam na modificação do sentido interpretativo do texto da Constituição Federal. Note-se, por oportuno, que o novo significado conferido deve atentar às balizas éticas e ter como parâmetro os ditames democráticos, legitimado socialmente, para se efetivar. Ou seja, não basta simplesmente interpretar da forma que mais convém, mas deve, além disso, ser resguardada a soberania do povo.

Entretanto, não raras vezes, o Judiciário é demandado a interpretar alguns dispositivos do sistema normativo, principalmente, quando se chocam os interesses do 
Executivo com os do Legislativo. Esse conflito de interesses é comum no sistema de governo presidencialista, como o brasileiro. Haveria, portanto, um controle do poder, em que o Judiciário passa a representar um contrapoder, como forma de, teoricamente, efetivar o denominado check and balances e aliviar as tensões institucionais.

O que se percebe é a expansão dos comandos judiciais para atuar em toda e qualquer seara, por meio da reinterpretação dos dispositivos normativos, muitas vezes, dotadas de duvidosa compatibilidade com a Constituição Federal. Estaria, portanto, configurada a realização de mutação inconstitucional dos magistrados, os quais agem como se legisladores fossem, identificando o tema com a judicialização da política.

\subsection{Caso Fernando Collor de Mello versus caso Dilma Rousseff}

De fato, ao Judiciário incumbe a interpretação final da Constituição Federal, mas questiona-se acerca dos parâmetros de sua atuação para a concretização dos ideais democráticos, pois recai-lhe a análise puramente do direito, por meio do uso de argumentos de princípios, ou seja, jurídicos, e, não, de políticas.

Durante o rito do impeachment no Senado Federal, o Presidente do Supremo Tribunal Federal (STF), responsável pela condução dos trabalhos, foi demandado por representantes do Partido dos Trabalhadores (PT) para que se manifestasse sobre a possibilidade de separação das votação em dois momentos: no primeiro, haveria a votação acerca da perda do cargo de Presidente da República, e, posteriormente, os Senadores deveriam demonstrar suas convicções sobre a aplicação da sanção de inabilitação, por oito anos, para o exercício de função pública. Ou seja, foi proposta uma demanda hermenêutica ao Presidente do STF para que interpretasse o dispositivo 52, parágrafo único, da Constituição Federal.

A surpresa concretizou-se quando o Presidente do Supremo Tribunal Federal, Ricardo Lewandowski, anuiu com as teses do Partido dos Trabalhadores. O resultado foi o seguinte: na primeira votação, por 61 votos a 20, os Senadores entenderam que a Presidente 
da República cometeu crime de responsabilidade, porém, na votação seguinte, por 42 votos a 36 (e três abstenções), os Parlamentares decidiram que não haveria a aplicação da sanção de inabilitação de Dilma para ocupar cargos públicos por oito anos.

O dispositivo constitucional é claro ao afirmar que a pena da condenação será a "perda do cargo, com inabilitação, por oito anos, para o exercício de função pública". A expressão "com” não traduz alternatividade, mas, sim, complementaridade das sanções. Além disso, para reforçar a incoerência da decisão do Presidente do STF, relembre-se o caso do impeachment do ex Presidente da República, Fernando Affonso Collor de Mello.

Em 29 de setembro de 1992, a Câmara dos Deputados votou pela abertura do impeachment de Fernando Collor, por 441 votos a 33. Posteriormente, em $1^{\circ}$ de outubro de 1992, foi instaurado o procedimento perante o Senado Federal e, já no dia 02 de outubro, houve o afastamento do Presidente e quem assumiu o cargo foi Itamar Franco. Em 29 de dezembro, começou o julgamento perante o Senado Federal e Fernando Collor pediu a renúncia do cargo, por meio de carta lida pelo advogado Moura Rocha, como forma de não se submeter às sanções advindas do crime de responsabilidade.

Curiosamente, no dia 30 de dezembro de 1992, apesar do ato de renúncia, Collor foi condenado à inabilitação por oito anos para o exercício de função pública e, em consequência, impetrou o mandado de segurança $n^{\circ} 21.689$ para resguardar-se da sanção imposta, o que foi indeferido pelo Supremo Tribunal Federal.

Naquele momento histórico, o Ministro Relator, Carlos Velloso (p. 22, online), utilizando o fundamento que Michel Temer havia exposto na sua obra "Elementos de Direito Constitucional", pronunciou-se sobre a impossibilidade de considerar a pena de inabilitação como acessória à pena de perda do cargo:

No regime da Constituição vigente, como na de 1946, em que foi editada a Lei $\mathrm{n}^{\circ}$ 1.079 , de 1950, a pena da inabilitação, para o exercício de qualquer função pública deve ser entendida como de aplicação necessária, em caso de condenação no processo de impeachment. Essa conclusão, como se acentuou, é a que se harmoniza com a própria finalidade do instituto e com seus princípios essenciais. (...) Não há falar, na verdade, na ordem constitucional brasileira, que a pena de 
inabilitação inscrita no parág. único do art. 52, da Constituição, tenha caráter de pena acessória.

Como visto acima, as penas não são autônomas. Uma decorre da outra e devem ser aplicadas em complementariedade. Ocorreu situação peculiar no caso Collor, pois o ex Presidente, ao renunciar, suscitou questão impeditiva de continuidade processual e consequente inaplicação de sanção perante o Supremo Tribunal Federal.

A maioria dos Ministros não acolheu o argumento presidencial, pois o ato de renúncia fora apresentado quando já iniciada a sessão de julgamento, no momento em que já se começava a tomar o depoimento de uma testemunha. Acatar o pedido de renúncia significaria anuir com burla ao sistema constitucional, como se verifica nas páginas 22 e 23 do voto do Ministro Relator:

\begin{abstract}
Também por isso não estava o Senado impedido de continuar no julgamento do impetrante. No caso, conforme já falamos, a renúncia foi apresentada na sessão de julgamento, quando o Presidente começava a tomar o depoimento de uma testemunha. $\mathrm{Na}$ ordem jurídica brasileira a administração pública e os agentes públicos, além de se submeterem ao princípio da legalidade, sujeitam-se aos princípios da impessoalidade e da moralidade administrativa ( $\mathrm{CF}$, art. 37), o que é reafirmado, de forma até redundante, na Lei $n^{\circ} 8.429$, de 2-6-92, artigo $4^{\circ}$. (...) A admissão do ato, com a finalidade pretendida, vale dizer, com a finalidade de impedir a conclusão de um julgamento já iniciado, seria ofensiva, também, ao princípio da moralidade administrativa, pressuposto de validade de qualquer ato de agente público. (grifo nosso)
\end{abstract}

Evidencia-se, portanto, que no processo de impeachment do Presidente Collor houve continuidade do julgamento para evitar que qualquer manobra presidencial desvirtuasse os comandos constitucionais, o que não significa compreender as penas do artigo 52, parágrafo único, da Constituição Federal como autônomas.

Em comparação ao impeachment da Presidenta Dilma, provoca surpresa ter-se uma votação expressiva favorável à perda do cargo e, em ato seguido, autorizar-se que não se aplique a sanção de inabilitação para o exercício de cargos ou funções públicas.

Esses, portanto, são os pontos de questionamento sobre o caso concreto. Alexis Tocqueville (1967, p.133) lembrava do papel dos juristas nas "tiranias que mal deixam o ar para o homem respirar". Tal fenômeno, comum na história, dá-se quando o rigor legal e 
constitucional é abandonado. Em resumo, estaria autorizado o Poder Judiciário a inovar na seara hermenêutica sobre um dispositivo constitucional cristalino, sob o manto de fazer Justiça?

\section{DEMOCRACIA E JURISDIÇÃO CONSTITUCIONAL: O PROTAGONISMO DO JUDICIÁRIO NAS QUESTÕES POLÍTICAS}

O impasse existe quando se confrontam os interesse tanto do Executivo quanto do Legislativo e as demandas são levadas à apreciação do Judiciário. Antoine Garapon (1999, p. 47-48) atenta, então, para a nova cena da democracia e expõe que, antes, a justiça ocupava lugar secundário no panorama democrático e, hoje, já se percebe uma inversão para ocupar o plano primário. O juiz passa a ser visto como um depósito de expectativas sociais e é demandado a se pronunciar, em substituição aos demais Poderes do Estado:

O espaço simbólico da democracia emigra silenciosamente do Estado para a justiça.
Em um sistema provedor, o Estado é todo-poderoso e pode tudo preencher, corrigir,
tudo suprir. Por isso, diante de suas falhas, a esperança se volta para a justiça. É
então nela e, portanto, for do Estado que se busca a consagração da ação política. O
sucesso da justiça é inversamente proporcional ao descrédito que afeta as
instituições políticas clássicas, causado pela crise de desinteresse e pela perda do
espirito público.

Além disso, diante de casos de tensão, o Judiciário é pressionado, como se a sua atuação devesse observância ao clamor popular e à vontade da maioria. Lenio Streck (2012, online) alerta para o fato de que não deve existir essa coalizão no Poder Judiciário, como existe entre Legislativo e Executivo, pois pressupõe-se uma atividade jurisdicional dotada de imparcialidade na sua atuação restrita à observância dos ditames normativos:

Quero demonstrar que, do mesmo modo como o Presidencialismo brasileiro é de
coalisão, enredado em atendimentos de pleitos políticos ad hoc, circunstância que
causa enormes problemas para a assim denominada "governabilidade" (por que
precisa de um ministro da Pesca que nem sabe pescar?), também o Supremo
Tribunal Federal acaba ingressando perigosamente nesse terreno de (atendimento a)
demandas de grupos. E também - e isso precisa ser dito - demandas provenientes
da falta de resolução dos problemas das liberdades públicas no plano dos demais
tribunais do país. Eles falham e tudo acaba no STF. Ele cresce. Mas sofre. E sangra
na legitimidade. 
Essa nova forma de atuação do Poder Judiciário enfatiza a jurisdição constitucional, com maior responsabilidade dos magistrados ao interpretarem dispositivos constitucionais. $\mathrm{O}$ juiz deixa de se apresentar como mero reprodutor da literalidade normativa e conquista postura de destaque no âmbito jurídico. Conforme menciona Luís Roberto Barroso (2009, p. 3), a atuação jurisdicional pode "ser direita, quando a norma constitucional discipline, ela própria, determinada situação da vida. Ou indireta, quando a Constituição sirva de parâmetro para sua validade. Nesse último caso, estar-se-á diante do controle de constitucionalidade". A jurisdição constitucional significa, então, a manifestação jurisdicional do Estado diante das demandas impostas, que só se legitima quando compatibilizada com os ditames democráticos.

\subsection{Mutação inconstitucional do artigo 52, parágrafo único, da Constituição Federal}

Ao se fazer um paralelo entre jurisdição constitucional e judicialização da política, um dos aspectos enfatizados é o fenômeno da mutação constitucional. Quando o Judiciário é instado a se manifestar sobre as demandas propostas, não raras vezes, reescreve a própria Constituição Federal, sob o argumento da segurança jurídica.

Entretanto, causa arrepio o fato de os Ministros do Supremo Tribunal Federal atuarem como se legisladores fossem e, mais que isso, tornarem públicas as reinterpretações do texto constitucional que atentam contra os ditames estabelecidos pelo Poder Constituinte. Ficam evidenciadas interpretações de duvidosa compatibilidade constitucional, o que se passa a denominar mutação inconstitucional.

Como se pode observar, em análise comparativa entre os impeachments de Collor e de Dilma, houve uma mudança interpretativa do artigo 52, parágrafo único, da Constituição Federal. No primeiro caso, ainda que tenha havido renúncia pelo ex Presidente, não se inviabilizou a apuração do crime de responsabilidade e sua consequente sanção. Não porque as penas de perda do cargo e inabilitação para demais cargos públicos por oito anos fossem consideradas autônomas, mas, como justificado anteriormente, o julgamento já havia sido iniciado e interromper o seu trâmite significaria anuir com uma burla ao texto constitucional. 
Já no segundo caso, enquanto o procedimento transcorria perante o Senado Federal, o Presidente do Supremo Tribunal Federal foi demandado sobre a possibilidade de divisão do rito em dois momentos. Em sua manifestação, concordou com a bipartição da seguinte forma: inicialmente, seria votada a existência, ou não, de crime de responsabilidade; e, depois, os Senadores deveriam se pronunciar sobre a aplicação da sanção à Presidente da República de inabilitação por oito anos para cargos públicos.

Vê-se, portanto, que houve uma mudança no entendimento do dispositivo constitucional. Mais que isso, a nova orientação representou uma alteração do texto constitucional sem a devida observância do trâmite formal de quórum específico para uma emenda constitucional.

Tal acontecimento traz ao estudo, brevemente, a teoria da representação argumentativa de autoria de Robert Alexy (2007, p. 301-302), a qual busca conciliar decisões volitivas e discursivas:

A chave para a solução desses problemas e, assim, para a solução do problema geral
da jurisdição constitucional é o conceito de representação argumentativa.
Representação é uma relação de dois polos entre um repraesentandum e um
repraesentans. No caso da legislação parlamentar a relação entre o repraesentandum
-o povo- e um repraesentans- o parlamento- é essencialmente determinada pela
eleição. Agora, é possível determinar um modelo de democracia que contém não
mais do que um sistema de tomada de decisões centralizado em torno dos conceitos
de eleição e regra da maioria. Esse seria um modelo de democracia puramente
decisional. Um conceito adequado de democracia deve, entretanto, compreender não
apenas a decisão, mas também o argumento. A inclusão da argumentação no
conceito de democracia cria a democracia deliberativa. A democracia deliberativa é
uma tentativa de institucionalizar o discurso enquanto um mecanismo possível de
tomada de decisões públicas. Por essa razão, a conexão entre o povo e o parlamento
não deve ser unicamente determinada por decisões expressas em eleições e votos,
mas também por argumentos. Nesse sentido, a representação do povo pelo
parlamento é, ao mesmo tempo, volitiva ou decisional e argumentativa ou
discursiva.

Robert Alexy afirma que a legitimidade da representação argumentativa dos magistrados se encontra na força do argumento utilizado na decisão, porém sua teoria deve ser criticada, pois não cabe ao Judiciário interferir em questões sociais. Sua legitimidade não advém da origem popular, como ocorre no Legislativo, mas, sim, de méritos próprios, conquistados pela aprovação em um concurso público. Por isso, o compromisso dos juízes 
atende aos ditames normativos e, por isso mesmo, não deve ceder às pressões que lhes são feitas.

Dessa maneira, consolidar a legitimidade do magistrado, por meio da força argumentativa de sua decisão, seria conferir-lhes poderes excessivos, superiores, inclusive, aos dos parlamentares, sob o manto da premissa de segurança jurídica. O caso concreto estudado neste trabalho permite demonstrar que, apesar de o Judiciário ter se manifestado, não houve qualquer garantia jurídica. Ao contrário: deu-se a reorientação jurisprudencial, o que está longe de garantir estabilidade de entendimentos.

\subsection{O Supremo Tribunal Federal e a incoerência argumentativa}

Desde a lei 1.079/50 e, posteriormente, enaltecido pela Constituição Federal, tem-se consolidado que as penas em um processo de impeachment são complementares. No caso de Fernando Collor, houve um pedido de renúncia que, por si só, não impediu a continuidade da instrução probatório e nem mesmo a aplicação de posterior sanção. Isso não significa, como visto em tópico anterior, que houve mudança de entendimento para se compreender as penas como autônomas. Foi apenas a forma que o Senado encontrou de não anuir com qualquer burla ao sistema normativo.

Já no mais recente caso envolvendo a apuração de crime de responsabilidade da Presidenta Dilma Rousseff, não houve renúncia, contudo, representantes do Partido dos Trabalhadores subscreveram pedido direcionado ao Presidente do Supremo Tribunal Federal para que dividisse a votação em dois momentos, como forma de reinterpretar o artigo 52, parágrafo único, da Constituição Federal. Curiosamente, a súplica foi aceita e, após a votação dos Senadores, a Presidente perdeu seu cargo político, mas não foi submetida à inabilitação para função pública por oito anos.

Percebe-se, portanto, uma mudança na orientação do Supremo Tribunal Federal, para possibilitar a autonomia das penas dispostas no claro texto constitucional. Sobre o tema, é 
interessante colacionar o entendimento do professor Lenio Streck (2016, online) sobre os limites da interpretação:

O Supremo Tribunal não dispõe do texto constitucional. O Judiciário não faz lei. A
questão, portanto, é saber que tipo de jurisdição constitucional queremos. Uma
jurisdição que obedeça a força normativa da Constituição, a coerência e a
integridade do direito tem muito mais condições de garantir a democracia do que
decisões pragmáticas e a construção de jurisprudência(s) defensiva(s). Se hoje é
possível dizer que onde está escrito $x$ leia-se $y$, o que impede que amanhã se diga
que "onde está escrito $n$, leia $p^{\prime \prime}$ ? Passado um tempo, todas as letras estarão
trocadas... Se me entendem a alegoria (ou metáfora).

A jurisdição constitucional não pode ser exercida como instrumento da judicialização da política. A limitação ocorre com o intuito de evitar o comprometimento da independência entre os poderes e da soberania popular. Dessa forma, o magistrado deve utilizar argumentos de princípios, ou seja, fundados no ordenamento jurídico para justificar suas decisões. Não pode adotar argumentos de política, em atendimento ao clamor público e, mais que isso, vir a mudar o entendimento de uma Corte, sem compromisso argumentativo com os precedentes.

Em distinto entendimento, porém, vê-se disseminada o conceito de uma jurisdição constitucional, como meio de reassegurar o poder detido pelas Supremas Cortes, o que revela o pensamento de que a justiça constitucional tutelaria o exercício da soberania popular, por meio do julgamento das demandas a ela impostas.

Ora, a função social do juiz não está adstrita ao respeito aos clamores populares ou pressões de grupos políticos. O magistrado tem uma responsabilidade política especifica para usar argumentos jurídicos em suas decisões, blindando o jurisdicionado de qualquer arbitrariedade, em razão de política, moral ou convicções pessoais. Ou seja, para que os juízes efetivamente contribuam com a integridade do Estado Democrático, devem, antes de tudo, terem o compromisso de levar os direitos a sério.

Portanto, em atenção ao ensino de Ronald Dworkin, ao juiz é atribuída uma responsabilidade política, que lhe impõe o dever ético de reconhecer direitos, conforme os ditames democráticos, com o intuito de evitar arbitrariedades baseadas em argumentos subjetivos ou políticos. 
A mudança interpretativa nos fez perceber que a última instância do Judiciário nacional não se vinculou ao que ela mesma decidiu. Essa inovação é perigosa e torna o campo hermenêutico pantanoso, pois enaltece o julgamento a partir de uma "jurisdição de coalizão", expressão que denigre e enfraquece os preceitos democráticos. 


\section{CONCLUSÃO}

Como observado no trabalho, o impeachment é um termo de origem inglesa que pode significar tanto o procedimento de apuração de um crime de responsabilidade, como a pena de perda do cargo, ambos em razão de impedimento para prosseguir nas funções anteriormente atribuída, em respeito, principalmente, à moralidade pública.

Foi examinado no primeiro capítulo o trâmite do impeachment, perante a Câmara dos Deputados e o Senado Federal. Dessa maneira, foram expostos os principais momentos do rito em cada uma das Casas Legislativas e, em especial, foi apresentado o resultado do julgamento da ADPF 378, a qual discutiu assuntos peculiares e, até então, sem definição jurídica sobre o procedimento.

O segundo enfoque conferido ao trabalho tratou do questionamento sobre a divisão da votação dos Senadores na fase final do processo de impeachment, com o intuito de tornar autônomas as penas aplicadas em caso de condenação por infração político-administrativa. $\mathrm{Ou}$ seja, alguns Senadores suscitaram questão de ordem e o Presidente do Supremo Tribunal Federal conferiu a possibilidade para que houvesse votação em separado sobre a condenação sem a aplicação da sanção de inabilitação para o exercício de funções públicas por oito anos, o que, de fato, ocorreu, por voto da maioria dos Senadores.

Além disso, foi realizada também análise comparativa da interpretação atribuída ao artigo 52, parágrafo único, da Constituição Federal nos casos de impeachment tanto de Collor de Mello quanto de Dilma Rousseff. Chegou-se à conclusão de que houve mudança na orientação da Suprema Corte, viabilizando uma releitura do dispositivo, sem a observância do procedimento formal de emenda constitucional.

Ainda que represente um benefício à então Presidenta Dilma Rousseff, ao permitir o desmembramento em duas votações, o Senado Federal alterou o texto constitucional, sem que houvesse observância do processo de deliberação para instituir emenda à Lei Suprema, por meio do quórum específico de dois terços dos membros de cada Casa Legislativa, em dois 
turnos de votação. Tratou-se, então, de uma mutação inconstitucional, sem atendimento aos mecanismos rígidos de alteração do texto, pela vontade de um número mínimo de parlamentares.

O terceiro capítulo abordou a temática da democracia e da jurisdição constitucional, sob o enfoque da mudança na orientação do Supremo Tribunal Federal, por meio do seu Presidente, ao permitir a possibilidade de desmembramento da votação sobre as penas perante o Senado Federal, o que ensejou o questionamento e crítica sobre a vinculação do Tribunal ao seu próprio entendimento anterior, sintetizado no caso Collor.

Evidenciou-se que, no caso paradigmático, o Supremo Tribunal Federal ignorou seu protagonismo jurídico, cedendo às pressões de determinado grupo político. Além de reescrever o dispositivo constitucional, o STF inaugurou novo posicionamento da Corte, ignorando todas as balizas normativas e argumentativas existentes até então.

De todo o exposto, conclui-se que a autorização atribuída pelo Presidente do Supremo Tribunal Federal configurou uma mutação inconstitucional, enfatizando o que se denomina de jurisdição de coalizão, a comprometer a estabilidade do sistema constitucional e da segurança jurídica. 


\section{REFERÊNCIAS}

ALBUQUERQUE, Felipe Braga. Direito e Política: pressupostos para a análise de questões políticas pelo judiciário à luz do princípio democrático. São Paulo: Editora Conceito, 2013.

ALEXY, Robert. Ponderação, jurisdição constitucional e representação popular. In: SOUZA NETO, Cláudio Pereira de; SARMENTO, Daniel (coord.). A constitucionalização do direito: fundamentos teóricos e aplicações específicas. Rio de Janeiro: Lumen Juris, 2007.

, Robert. Teoria dos Direitos Fundamentais. 2.ed. São Paulo: Malheiros, 2012.

ÁVILA, Humberto. Teoria dos princípios: da definição à aplicação dos princípios jurídicos. 7.ed. São Paulo: Malheiros, 2007.

BARROSO, Luís Roberto. O Controle de constitucionalidade no direito brasileiro. 4. ed. São Paulo: Saraiva, 2009.

BERCOVICI, Gilberto. Soberania e Constituição: para uma crítica do constitucionalismo. São Paulo: Quartier Latin, 2008.

BOBBIO, Norberto. Estado, Governo e Sociedade: Para uma teoria geral da política. 15. ed. Rio de Janeiro: Paz e Terra, 2009.

BORJA, Rodrigo. Derecho político y constitucional. 2. ed. México: Fondo de Cultura Económica, 1992.

BRASIL. Constituição Federal de 1988. Disponível em: <http://www.planalto.gov.br/ccivil_ 03/constituicao/constituicaocompilado.htm>. Acesso em: 2 set. 2016.

Supremo Tribunal Federal. Mandado de Segurança no 21.689-DF. Relator(a): Min. Carlos Velloso. Julgamento: 16/12/1993. Órgão Julgador: Tribunal Pleno. DJ 07-041995.Disponívelem: <http://www.stf.jus.br/arquivo/cms/sobrestfconhecastfjulgamentohistoric o/anexo/ms21689.pdf> Acesso em: 10 set. 2016.

DWORKIN, Ronald. Levando os direitos a sério. Trad: Nelson Boeira.São Paulo: Martins Fontes, 2002.

GARAPON, Antoine. O juiz e a democracia: o guardião das promessas. Tradução: Maria Luiza de Carvalho. Rio de Janeiro: Revan, 1999. 
LIMA, Martonio Mont'Alverne Barreto. Justiça constitucional e democracia: perspectivas para o papel do Poder Judiciário. Rev. da Procuradoria-Geral da República n⿳08. São Paulo: RT, Jan-Jun, 1996.

MAUS, Ingeborg. O Judiciário como superego da sociedade: o papel da atividade jurisprudencial na "sociedade órfã". Trad. Martonio Lima e Paulo Albuquerque. Revista Novos Estudos CEBRAP, n ${ }^{\text {58, nov. } 2000 .}$

PIÇARRA, Nuno. A separação dos poderes como doutrina e princípio constitucional: um contributo para o estudo das suas origens e evolução. Coimbra: Coimbra Limitada, 1989.

RODRIGUES, Francisco Lisboa. A criação judicial do direito - o papel do Supremo Tribunal Federal como legislador positivo. Dissertação (2008) 97f. Mestrado em Mestrado em Direito Constitucional, pela Universidade de Fortaleza - UNIFOR, 2008.

STRECK, Lenio Luiz; LIMA, Martonio Mont'Alverne Barreto. Controle preventivo e juriscocracia. Disponível em: <www.conjur.com.br/2011-jan-29/nao-espaco-controlepreventivo-constitucionalidade-brasil\#autores\%23autores> Acesso em: 10 set. 2016.

STRECK, Lenio. Os limites da interpretação e a democracia. Disponível em: <http://www.conjur.com.br/2016-jun-25/diario-classe-limites-interpretacao-democracia> Acesso em: 10 set 2016.

O Supremo, o contramajoristarismo e o 'pomo de ouro'. Disponível em: <http://www.conjur.com.br/2012-jul-12/senso-incomum-stf-contramajoritarismo-pomoouro> Acesso em: 12 set 2016.

TOCQUEVILLE, Alexis de. Die gesellschaftliche und politische Zustände Frankreiches vor und nach 1789. In: TOCQUEVILLE, Alexis de, Das Zeitalter der Gleichheit - Auswahl aus Werken und Briefen, 2. Auflage, Köln/Opladen: Westdeutscher Verlag, 1967. 